\title{
LIVRO: FIANS, GUILHERME. ENTRE CRIANÇAS, PERSONAGENS E MONSTROS: UMA ETNOGRAFIA DE BRINCADEIRAS INFANTIS. RIO DE JANEIRO. EDITORA PONTEIO, 2015.
}

\author{
CLAUDIA PIMENTEL ${ }^{1}$
}

Com 26 anos, Guilherme Fians publica sua dissertação de mestrado aprimorada em conteúdo e estilo. Sua pesquisa, realizada no Programa de Pós-graduação em Antropologia Social do Museu Nacional/Universidade Federal do Rio de Janeiro (PPGAS), traz questões pouco exploradas pelo campo da Antropologia. Seu trabalho inova por ser uma pesquisa empírica da infância num campo tradicionalmente conhecido por dar visibilidade a culturas exóticas de forma que se perceba o outro nos seus próprios termos, ou seja, a partir de seus valores e sentidos. Fians parte do princípio de que as crianças produzem significados sobre o mundo e seus elementos, tais como papéis sociais, personagens de desenhos animados, brinquedos, professores, outras crianças. Seu estudo tem como objetivo perceber, nos termos das crianças, como elas estabelecem em suas conversas "o que é sério" e "o que é de brincadeira". Para tanto, faz uma descrição densa de brincadeiras de crianças de uma turma de educação infantil de uma escola particular do Rio de Janeiro. A escola não é problematizada enquanto instituição, mas como espaço da etnografia.

No prefácio, a professora titular do PPGAS Bruna Franchetto explica que antropólogos tradicionais, vitorianos ou evolucionistas procuraram estabelecer analogias entre as crianças das sociedades ocidentais e os adultos das chamadas sociedades "primitivas", percebendo neles traços tanto de inocência como de lógica descolada da realidade. A partir dessa questão aparentemente confinada a teorias ultrapassadas, mas presente no senso comum, o autor lança suas primeiras questões de estudo. Duvidando dessa aproximação e considerando que as crianças não têm sido tomadas a sério, o autor justifica a necessidade de ir direto à fonte e investigar, por meio de uma pesquisa de caráter etnográfico, como as crianças percebem, inventam e significam o mundo.

1 Professora do Departamento de Ensino Superior do Instituto Nacional de Educação de Surdos (INES) e professora associada do Programa de Pós-graduação em Educação da Universidade Federal de Alagoas (UFAL). 
O autor defende que as crianças sabem perfeitamente quando estão na brincadeira ou quando estão levando a sério diferentes situações, mas que não é tão simples reduzir o tema a polarizações entre realidade e imaginação, verdade e mentira, fato e ficção. Procurando superar essas dicotomias, o estudo, nas palavras do autor, dispensa o grande divisor entre conhecimento e crença e busca apreender o que acontece de verdade quando as crianças brincam.

Sabe-se que a compreensão de que as crianças estão inseridas na cultura e que produzem cultura vem sendo difundida pelos estudos da Sociologia da Infância. $\mathrm{O}$ autor reconhece as contribuições do campo sociológico e realiza um levantamento das principais referências teóricas sobre a brincadeira, tendo o mérito de recuperar o estudo de Florestan Fernandes, da década de 1940, sobre as "trocinhas" do Bom Retiro, considerado pioneiro no Brasil.

Para apresentar as crianças pela sua positividade, o autor recorre a teorias que definem a infância como categoria estrutural permanente da sociedade. As crianças integrariam uma categoria geracional a cada momento, pois elas crescem e se tornam adultas, mas a infância permanece sendo continuamente renovada. Alguns estudos, ao tomarem as diferenças geracionais, muitas vezes dão a impressão de que as relações entre pares das crianças não têm conexões com o que circula entre pessoas de diferentes idades. Fians afirma que a segmentação radical entre as gerações reduz as experiências compartilhadas entre as pessoas que habitam determinado tempo e espaço, o que pode levar a crer que as produções de gerações distintas são incomunicáveis. Fians opta por reconhecer que não é possível isolar as gerações para fins de estudo sem que se perca o contexto em que as crianças estão inseridas, principalmente quando se estuda a escola.

A observação das negociações entre as crianças revelou que os momentos de conflito são privilegiados para perceber e analisar as definições e redefinições sobre o que é sério e o que é de brincadeira. A brincadeira tem sempre um início negociado, mantido por mensagens e combinados, e se encerra de forma similar. O fim da brincadeira, em ambiente escolar, pode ser provocado também por uma convocação para que as crianças deixem o pátio e voltem para a sala de aula, pela saída de um dos participantes da brincadeira ou ainda por constantes desentendimentos, brigas e equívocos, que são considerados importantes para o conhecimento das redefinições que as crianças fazem sobre estarem brincando e sobre os papéis que exercem entre outros combinados necessários sobre estar brincando ou não. Essas definições e redefinições são tomadas pelo autor como metacomunicação, ou seja, negociações e reflexões sobre as regras que estão sendo estabelecidas com o(s) outro(s). 
Como várias pessoas entram nessas negociações, o autor evidencia que não é possível reduzir as relações na escola a uma oposição entre adultos e crianças, culturas infantis e culturas adultas, pois as experiências são vividas conjuntamente, a partir de múltiplas perspectivas, e não a partir de ideias restritas a uma única geração.

A brincadeira é estudada tradicionalmente pela Psicologia, sendo Vygotsky importante referência. Para Vygotsky, a brincadeira favorece a elaboração de campos semânticos e a compreensão da cultura por parte das crianças. No entanto, a abordagem psicológica na maioria das vezes não traz evidências sobre o que realmente as crianças fazem quando brincam. O estudo de Fians não só investe em análises sobre aquilo que ele denomina de metacomunicação das crianças quando brincam como realiza um inventário descritivo de brincadeiras e seus contextos. Vale um olhar atento às notas de rodapé que trazem descrições de jogos e brincadeiras contemporâneas e tradicionais, situando o leitor não familiarizado sobre o que anda circulando entre as crianças.

A transcrição das falas das crianças em discurso direto traz evidências de que o faz de conta não é simplesmente uma ficção lúdica e que verdades e mentirinhas (como as crianças algumas vezes se referem à brincadeira) têm consequências reais na vida das crianças e dos adultos no ambiente escolar. As crianças demonstram uma série de conhecimentos ao negociarem personagens e situações que compõem as brincadeiras. A realidade permeia e constitui os enredos. Contudo, as crianças negociam os termos que serão mantidos na brincadeira. Por exemplo, ao incorporarem um personagem de desenho animado em sua brincadeira, negociam se tal personagem manterá determinadas características ou não, e como uma determinada criança imitará certo personagem, considerando o seu jeito de ser. Por ter clareza de que está tentando imitar o personagem do seu jeito, essas apropriações são constantemente negociadas entre os participantes das brincadeiras, o que acaba gerando vivências emocionais reais e muitas vezes os adultos precisam intervir para acalmar os ânimos. Nem sempre as crianças estão dispostas a assumir os papéis negociados. Algumas vezes cedem apenas para poder participar. Os limites são negociados naquilo que pode ser considerado um devir de tal personagem ou situação, algo que está no limite da possibilidade de ser semelhante à realidade, mas que nunca coincide com o que seria uma suposta referência cultural. Assim, ao brincar de "ser cachorro", por exemplo, a criança pode chupar chupeta e se comportar como um bebê, na medida em que o grupo que brinca veja aproximações entre o devir bebê, o devir cachorro e a possibilidade real de determinada criança entrar numa brincadeira em que alguns personagens já estão definidos, no caso uma brincadeira de 
família. Não há uma relação mimética direta uma vez que o sistema estabelecido não é de semelhança nem de analogia, pois tanto a criança que brinca permanece com sua identidade como o personagem se transforma na ação da brincadeira.

Ao trazer o conflito como momento valioso para observação de negociações e metacomunicação entre as crianças, Fians demonstra como a brincadeira não é mero passatempo ameno. Os sentimentos estão presentes e muitas vezes as lágrimas também. As vivências são reais ainda que as crianças saibam que estão brincando. Os adultos interferem muitas vezes nas brincadeiras seja para marcar os tempos próprios à escola como também para serenar os conflitos. Muitas vezes os adultos não entendem que as crianças ainda estão brincando e é a vez deles se incomodarem, impondo limites para que suas propostas pedagógicas prevaleçam.

O estudo perde força ao concluir que há um amadurecimento das crianças e que as demarcações flutuantes entre verdades e mentiras aos poucos cedem lugar a definições mais rígidas sobre realidade e fantasia, pois na ideia do amadurecimento estão as bases das teorias evolucionistas refutadas pelo autor. A escolha por concluir de forma a estabelecer comparações entre os conceitos dos adultos às definições das crianças reitera as demarcações de fronteiras geracionais também refutadas por ele. Em suas considerações finais, Fians distancia-se de algumas evidências importantes que foram registradas ao longo do estudo, tais como a presença de conflitos na elaboração de conceitos complexos como os envolvidos na distinção entre "o que é sério" e "o que é de brincadeira", o que é fato e o que é ficção. Ao optar por realizar uma etnografia numa escola, o autor contribui para difundir o aporte antropológico para os estudos da infância em espaços educativos, mas resta ainda encontrar caminhos para que a possibilidade de conhecer o outro através dos seus próprios termos, proposta pela Antropologia, possa sustentar um olhar crítico para a escola, apontando caminhos para uma pedagogia mais dialógica, para que as gerações possam de fato considerar seus pontos de vista diversos, sem evitar ou ocultar conflitos, mas reconhecendo neles importantes oportunidades de negociação de sentidos e de elaborações conceituais. 